\title{
AEROMONAS SPP. AND MICROBIAL INDICATORS IN RAW DRINKING WATER SOURCES
}

\author{
Marisa Di Bari; Hachich Elayse M.; Melo Adalgisa M. J.; Sato, Maria I. Z.* \\ Companhia de Tecnologia de Saneamento Ambiental, São Paulo, SP, Brasil.
}

Submitted: October 04, 2006; Returned to authors for corrections: February 08, 2007; Approved: July 20, 2007.

\begin{abstract}
Aeromonas species are autochtonous in the aquatic environment and some of them have been associated with health effects like wound infections, septicemia and diarrhoeal illness. In this study, the occurrence of Aeromonas spp. and microbial indicators in raw drinking water from wells, springs, fountains and mineral waters was evaluated. A total of 126 water samples was analyzed for Aeromonas spp. by the membrane filtration technique using ADA media and by P/A test. Typical colonies of Aeromonas spp. were submitted to biochemical tests for species differentiation. Toxin production was tested using Y-1 mouse adrenal cells. Coliforms and heterotrophic bacteria were enumerated by membrane filtration and pour plate techniques, respectively. P. aeruginosa, $C$. perfringens and fecal streptococci were determined by P/A method. Aeromonas spp. were isolated in $36.5 \%$ of the samples, whereas total and thermotolerant coliforms were detected in $51.2 \%$ and in $23.8 \%$ of the samples, respectively. C. perfringens, fecal streptococci and P. aeruginosa were present in $16.5 \%, 20.4 \%$ and $3.8 \%$ of the samples, respectively. The concentrations of heterotrophic bacteria were higher than $1,0 \times 10^{3} \mathrm{CFU} / \mathrm{mL}$ in $52.5 \%$ of the samples. A. hydrophila was the most frequent species, followed by A. allosaccharophila, A. jandaei, A.sobria and HG2. A heat label toxin was detected in 13 from the 58 strains tested. These data show that the drinking water sources analyzed can represent a risk for human health. It is important to consider that wells and springs are used as drinking water supply in poor areas and rural regions, where undernourished people more susceptible to infections by these microorganisms predominate.
\end{abstract}

Key words: Aeromonas, raw drinking water, microbial indicators, heat labile toxin

\section{INTRODUCTION}

The importance of Aeromonas spp. as an emergent human pathogen has increased significantly in the last years $(18,21)$. Aeromonas spp. can cause wound infections and septicaemia $(20,26,29)$ and have been associated with diarrhoeal illness worldwide $(13,16,34)$. There are presently 22 phenospecies and 18 genomospecies in the genus Aeromonas spp. (24) and at least 9 of them have been implicated in human diseases $(18,24)$. A. hydrophila (HG-1), A. caviae (HG-4), A. veronii (HG-8), A. jandaei (HG-9), A. schubertii (HG-12) and A. trota (HG-14) are more frequently associated with clinical specimens $(22,24)$. Some species are pathogens for fish and amphibians.

The normal habitat of Aeromonas spp. is the aquatic ecosystems and their presence have been reported frequently by several authors in groundwater, drinking water at treatment plants and in water distribution systems, natural mineral springs, surface waters (fresh, estuarine and marine) and crude and treated sewage $(1,5,6,8,16,22,23,27,35)$. Exposure to water contaminated with Aeromonas spp., through ingestion or contact, have been associated with human infections that are particularly hazardous in immunocompromised patients $(8,20)$. Recently, the US Environmental Protection Agency proposed Aeromonas hydrophila as one of the contaminants of concern in waterborne diseases (36).

In the present study the occurrence of Aeromonas species in drinking water proceeding from wells, springs, fountains and mineral waters was investigated. Such drinking waters are usually consumed without any treatment and can be considered as a source of gastrointestinal infections. The prevalence of

*Corresponding Author. Mailing address: CETESB - Av. Prof. Frederico Hermann Jr. 345 cep 05459-900 São Paulo, SP - Brasil. Tel.: (11) $3133-3541$ ou (11) 3133-3982. E-mail: mariaz@ cetesbnet.sp.gov.br 
aeromonads in relation to the microbiological bacterial indicators was also studied.

\section{MATERIALAND METHODS}

\section{Sampling}

A total of 118 water samples collected over a 12 month period from wells $(n=97)$, springs $(n=11)$ and fountains $(n=10)$ examined for compliance with Brazilian Legislation in the Laboratory of Microbiology of CETESB (São Paulo, SP, Brazil) were selected for this study. Eight samples of mineral water were also examined. These water sources have not been submitted to any antimicrobial treatment. Sample collection was performed according to the APHA Standard Methods (2) in sterile disposable bottles, chilled for storage and transportation. Samples were examined within 24 hours.

\section{Bacteriological Methods}

Water samples were assayed for Aeromonas spp. $(\mathrm{n}=126)$, total and thermotolerant coliforms $(\mathrm{n}=126)$, heterotrophic bacteria $(\mathrm{n}=120)$, fecal streptococci $(\mathrm{n}=103)$, Pseudomonas aeruginosa $(\mathrm{n}=103)$ and Clostridium perfringens $(\mathrm{n}=103)$.

Coliforms were enumerated by the membrane filtration technique and heterotrophic bacteria by the pour plate technique, according to APHA (2).

Fecal streptococci, P.aeruginosa and C. perfringens were determined by P/A assay $(9,10)$. For enumeration of Aeromonas spp. the membrane filtration technique using ampicillin-dextrin agar medium (ADA), developed by Havelaar et al. was used (15). The plates were incubated at $30^{\circ} \mathrm{C}$ for 18 to 24 hours. Typical yellow colonies (dextrin fermentation) were counted and five of them were transferred to nutrient agar for oxidase test. Oxidase positive strains were inoculated into IAL medium (28) for an initial screening. At least one presumptive Aeromonas spp isolate of each sample was submitted to the following biochemical tests for genus confirmation and species differentiation $(3,30)$ : decarboxylation of lysine and ornithine, dihydrolation of arginine, production of indole, VP reaction, fermentation of glucose, arabinose, inositol, lactose, mannose, mannitol, salicin, sorbitol and sucrose, production of gas from glucose, hydrolysis of aesculin, ONPG and gelatin, susceptibility to O/129 (50 and $150 \mu \mathrm{g}$ ), growth in the absence of sodium chloride, motility and nitrate reduction.

Aeromonas spp. was also ivestigated by P/A tests. Positive P/A presumptive broth was streaked on ADA agar medium and identification was carried out as described above.

\section{Haemolysin production}

Haemolysin production was evaluated on 5\% sheep blood agar (SBA) as follows: The 4-5h culture of each Aeromonas spp. strain obtained in brain heart infusion broth (BHIB) was inoculated in SBA. After incubation at $35^{\circ} \mathrm{C}$ for 24 and $48 \mathrm{~h}$ the plates were examined for the presence of alpha- or betahaemolysis (35).

\section{Heat labile (LT) enterotoxin assay}

Enterotoxin production was tested in Y-1 mouse adrenal cells according to Sack and Sack (32). Tryptic soy broth containing $0.6 \%$ of yeast extract was inoculated with a fresh culture of the Aeromonas spp. strain (BHIB, $4 \mathrm{~h}$ growth). After incubation at $35^{\circ} \mathrm{C}$ for $18 \mathrm{~h}$ in a shaker, cell free preparations were obtained by centrifugation of the cultures at $10,000 \mathrm{xg}$ for 30 minutes at $5^{\circ} \mathrm{C}$ followed by filtration through membrane filter $(0.45 \mu \mathrm{m})$. Supernatant preparations were stored at $-20^{\circ} \mathrm{C}$ if it was not possible to test the material within $24 \mathrm{~h}$. Two aliquots ( $25 \mu \mathrm{l}$ each) of the supernatant were inoculated in Y-1 cells (96 well microtitration plates) and the cytotoxic effect was observed after incubation at $37^{\circ} \mathrm{C}$ during 6 and 18 hours. Positive and negative controls were performed in parallel with each assay. The heat stability of the samples was tested exposing the supernatants of the positive strains to $56^{\circ} \mathrm{C}$ for 15 minutes.

\section{RESULTS AND DISCUSSION}

The percentage of positive samples for the bacteriological indicators and Aeromonas spp. is shown in Fig. 1. A total of 65 samples out of 126 tested were positive for total coliforms. Thermotolerant coliforms and fecal streptococci were present in more than $20 \%$ of the water samples and heterotrophic bacteria were detected in densities higher than $1,0 \times 10^{3} \mathrm{CFU} / 100$ $\mathrm{mL}$ in $52.5 \%$ of the samples. C. perfringens and P. aeruginosa were isolated in $17 \%$ and $4 \%$ of the samples, respectively. Even lower percentages of positive samples for $C$. perfringens and $P$. aeruginosa were obtained by Clark (11).

Aeromonas species were recovered from 46 samples (36.5\%) and the percentage of positive samples was higher in less

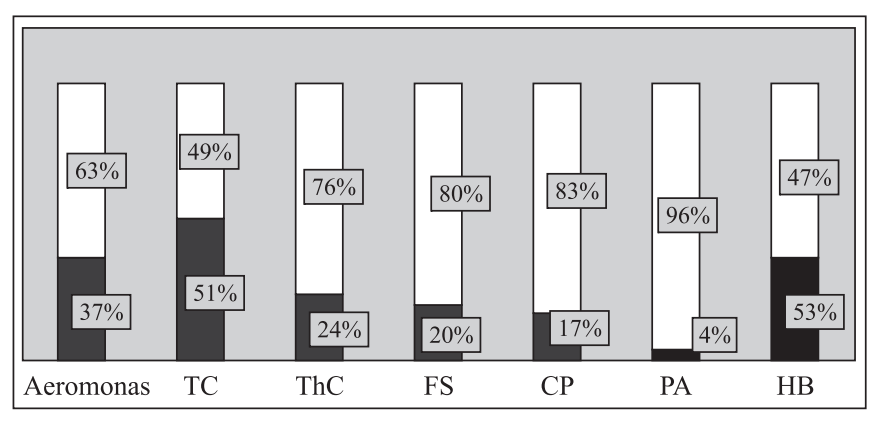

Figure 1. Percentage of positive ( $\square$ ) and negative $(\square)$ samples for Aeromonas spp., total (TC) and thermotolerant (ThC) coliforms, fecal streptococci (FS), C. perfringens (CP), $P$. aeruginosa $(\mathrm{PA})$ and for heterotrophic bacteria $(\mathrm{HB})$ in counts over $1,000 \mathrm{CFU} / 100 \mathrm{~mL}$. 
protected raw drinking water sources, such as springs and fountains than in the wells (Table 1). Massa et al. (25) reported Aeromonas spp. in $25 \%$ of well water samples from Lecce, Italy. These data are similar to the results obtained in this study

Table 1. Number and percentage of Aeromonas spp. positive samples according to the origin of the drinking water sample and the analytical technique.

\begin{tabular}{|c|c|c|c|c|c|c|}
\hline \multirow[t]{2}{*}{$\begin{array}{l}\text { Water } \\
\text { Source }\end{array}$} & \multicolumn{2}{|c|}{$\begin{array}{l}\text { Membrane } \\
\text { Filtration }\end{array}$} & \multicolumn{2}{|c|}{$\mathrm{P} / \mathrm{A}$} & \multicolumn{2}{|c|}{ Total } \\
\hline & Tested & $\begin{array}{c}\text { Positive } \\
\text { (\%) }\end{array}$ & Tested & $\begin{array}{c}\text { Positive } \\
(\%)\end{array}$ & Tested & $\begin{array}{c}\text { Positive } \\
(\%)\end{array}$ \\
\hline Well & 91 & $28(31)$ & 80 & $18(22.5)$ & 97 & $29(30.3)$ \\
\hline Spring & 11 & 7 (63.6) & 8 & 0 & 11 & $7(63.6)$ \\
\hline Fountain & 10 & $10(100)$ & 10 & $2(20)$ & 10 & $10(100)$ \\
\hline Mineral Water & 8 & 0 & 5 & 0 & 8 & 0 \\
\hline Total & 120 & $45(37.9)$ & 103 & $20(19.4)$ & 126 & $46(36.5)$ \\
\hline
\end{tabular}

(30.3\%), but lower than the $48.7 \%$ reported by Ghenghesh et al. (12) in Tripoli, Lybia.

The membrane filtration technique showed better results than the P/A method for recovery of Aeromonas spp. from the different water sources (Table 1). Considering that in both techniques the same sample volume (100 $\mathrm{mL}$ ) and selective medium (ADA) are used, the lower percentage of positive samples obtained with P/A test could be attributed to the competitive flora in the P/A presumptive broth which is a medium favorable to the growth of different microbial indicators $(9,10)$.

The counts of total and thermotolerant coliforms, heterotrophic bacteria and Aeromonas spp in the water samples are shown in Table 2. All the water sources presented maximum Aeromonas spp. counts higher than $200 \mathrm{CFU} / 100 \mathrm{~mL}$. The fountain water samples showed the highest geometric mean and median for the bacterial indicators and Aeromonas spp., followed by the spring and well water samples. Aeromonas spp. was absent in the mineral water samples.

Table 2. Counts of Aeromonas spp, total and thermotolerant coliforms and heterotrofic bacteria in the different water sources.

\begin{tabular}{|c|c|c|c|c|c|}
\hline Water Source & & $\begin{array}{l}\text { Total coliforms } \\
\text { CFU/100mL }\end{array}$ & $\begin{array}{c}\text { Thermotolerant } \\
\text { coliforms } \\
\text { CFU/100mL }\end{array}$ & $\begin{array}{c}\text { Heterotrofic } \\
\text { Bacteria } \\
\text { CFU/mL }\end{array}$ & $\begin{array}{c}\text { Aeromonas spp } \\
\text { CFU/100mL }\end{array}$ \\
\hline Well & $\begin{array}{l}\operatorname{Min}^{\mathrm{a}} \\
\operatorname{Max}^{\mathrm{b}} \\
\mathrm{Gm}^{\mathrm{c}} \\
\text { Med }^{\mathrm{d}} \\
\text { Quart }^{\mathrm{e}}\end{array}$ & $\begin{array}{c}<1 \\
3.0 \times 10^{3} \\
6.5 \\
<1 \\
42.5\end{array}$ & $\begin{array}{l}<1 \\
120 \\
1.6 \\
<1 \\
<1\end{array}$ & $\begin{array}{c}<1 \\
>5.7 \times 10^{3} \\
421 \\
900 \\
>5.7 \times 10^{3}\end{array}$ & $\begin{array}{c}<1 \\
>200 \\
3.9 \\
<1 \\
199\end{array}$ \\
\hline Spring & $\begin{array}{l}\text { Min } \\
\text { Max } \\
\text { Gm } \\
\text { Med } \\
\text { Quart }\end{array}$ & $\begin{array}{c}<1 \\
2.3 \times 10^{3} \\
21.6 \\
44 \\
112\end{array}$ & $\begin{array}{c}<1 \\
>200 \\
5.9 \\
3 \\
17.5\end{array}$ & $\begin{array}{c}65 \\
>5.7 \times 10^{3} \\
548 \\
900 \\
>5.7 \times 10^{3}\end{array}$ & $\begin{array}{c}<1 \\
>200 \\
8.4 \\
3 \\
130.5\end{array}$ \\
\hline Fountain & $\begin{array}{l}\text { Min } \\
\text { Max } \\
\text { Gm } \\
\text { Med } \\
\text { Quart }\end{array}$ & $\begin{array}{c}<1 \\
2.3 \times 10^{3} \\
116.5 \\
253.5 \\
419\end{array}$ & $\begin{array}{c}<1 \\
>200 \\
56 \\
1 \\
151\end{array}$ & $\begin{array}{c}37 \\
>5.7 \times 10^{3} \\
402 \\
235 \\
3.31 \times 10^{3}\end{array}$ & $\begin{array}{c}16 \\
>200 \\
56.7 \\
117.5 \\
>200\end{array}$ \\
\hline Mineral Water & $\begin{array}{l}\text { Min } \\
\text { Max } \\
\text { Gm } \\
\text { Med } \\
\text { Quart }\end{array}$ & $\begin{array}{c}<1 \\
>200 \\
1.9 \\
<1 \\
<1\end{array}$ & $\begin{array}{c}<1 \\
>200 \\
1.9 \\
<1 \\
<1\end{array}$ & $\begin{array}{c}1.1 \times 10^{3} \\
>5.7 \times 10^{3} \\
3.2 \times 10^{3} \\
>5.7 \times 10^{3} \\
>5.7 \times 10^{3}\end{array}$ & $\begin{array}{l}<1 \\
<1 \\
<1 \\
<1 \\
<1\end{array}$ \\
\hline
\end{tabular}

a: minimum; b: maximum; c: geometric mean; d: median; e: $3^{\text {rd }}$ quartile. 
However, the presence of more than $1.0 \times 10^{3} \mathrm{CFU} / \mathrm{mL}$ of heterotrophic bacteria in these samples may have interfered in the detection of these microorganisms (2).

The different ranges of bacteriological indicators counts were compared with the positivity for Aeromonas spp. in order to determine a possible association between these bacteria and the routinely used pollution indicators (Table 3). Although the highest percentage of Aeromonas spp. positive samples was in samples with counts of total coliforms superior to 100 CFU/100 mL, Aeromonas spp. was also detected in well water samples where these indicators were absent. It was not observed an association between Aeromonas spp. and termotholerant coliforms, the opportunistic pathogen was commonly isolated in the absence of faecal contamination. Hirotani et al. (17) studied the correlation of A.hydrophila and fecal indicators and also observed that the presence of this microorganism was not associated with human fecal contamination. Araujo et al. (4) investigated a possible correlation between the presence of mesophilic aeromonads and the number of fecal coliforms and found a significant relationship only in polluted waters.

In the Netherlands, Aeromonas spp. are frequently present in drinking water in numbers varying between $<1$ and $1,0 \times 10^{4}$

Table 3. Frequency of Aeromonas spp. positive samples, according to the concentrations of total coliforms, thermotolerant coliforms and heterotrophic bacteria in different water sources.

\begin{tabular}{cccc}
\hline & \multicolumn{3}{c}{ No. (\%) of positive } \\
Bacteriological indicator $^{a}$ & \multicolumn{3}{c}{ samples for Aeromonas } \\
\cline { 2 - 4 } & Well & Spring & Fountain \\
\hline Total Coliform & & & \\
$<1$ & $9(32)$ & 0 & 0 \\
$1-10$ & $4(14)$ & $2(29)$ & $2(20)$ \\
$11-100$ & $5(18)$ & $1(14)$ & $1(10)$ \\
$>100$ & $10(36)$ & $4(57)$ & $7(70)$ \\
Thermotolerant Coliforms & & & \\
$<1$ & $17(61)$ & $3(43)$ & $5(50)$ \\
$1-10$ & $4(14)$ & 0 & $2(20)$ \\
$11-100$ & $4(14)$ & $1(14)$ & 0 \\
$>100$ & $3(11)$ & $3(43)$ & $3(30)$ \\
Heterotrofic Bacteria & & & \\
$<1$ & $7(25)$ & 0 & 0 \\
$1-500$ & $2(7)$ & $2(29)$ & $6(60)$ \\
$501-1000$ & $19(68)$ & $1(14)$ & 0 \\
$>1000$ & 0 & $4(57)$ & $4(40)$ \\
\hline
\end{tabular}

a. Total and thermotolerant coliforms: CFU/100 mL; heterotrophic bacteria: $\mathrm{CFU} / \mathrm{mL}$.
CFU/100 $\mathrm{mL}$ and this organism can be isolated from 1-6\% of faecal samples of patients with diarrhoea (16). In Italy, Aeromonas spp. were detected in water samples in counts ranging from 26 to $1609 \mathrm{CFU} / 250 \mathrm{~mL}$ (25).

The results of species identification are shown in Table 4. A. hydrophila was the most common species (48.3\%), followed by A. allosacharophila (17.2\%) and A. jandaei (10.3\%). A. trota, A. sobria and HG 2 were also isolated. It was not possible to determine the species of ten out of 58 isolates submitted to the identification tests. These results are similar to the data reported in the literature, where A. hydrophila is the predominant species in freshwater and municipal drinking water supplies $(12,22,31)$. The Aeromonas species that can cause human infections are $A$. hydrophila, A. caviae, A. veronii, A. jandaei, A. schubertii, A. trota and A. media $(22,24)$. In the Northwest from Brazil, Aeromonas spp. were isolated from patients with diarrhea in a region where cholera cases were also occurring (Brazilian Health Department, personal communication).

Fifty-four strains of Aeromonas spp. were positive for haemolysin production. A thermolabile enterotoxin was detected in 13 out of 58 strains: A. hydrophila $(\mathrm{n}=6)$, A. jandaei $(\mathrm{n}=3)$, A. allosacharophila $(\mathrm{n}=2)$ and Aeromonas $\mathrm{sp}(\mathrm{n}=2)$.

There is little information available about toxin production by Aeromonas isolated from the environment $(33,34)$. Some authors consider the $\beta$-hemolysis production as a virulence factor for Aeromonas species $(7,33)$. In the present study, 22\% of Aeromonas strains produced LT enterotoxin and 93\% were haemolytic and can be therefore considered potentially enteropathogenic.

The data show that the raw drinking water sources studied represent a risk for human health and that commonly used bacteriological indicators cannot predict the presence of these potentially enteropathogenic microorganisms in such waters. Wells and springs are used as drinking water supply in poor areas and rural regions, where undernourished people more susceptible to infections by these microorganisms predominate, therefore disinfection practices and alternative sources of drinking water must be considered.

Table 4. Percentage of Aeromonas species in raw drinking water samples $(\mathrm{n}=58)$

\begin{tabular}{lc}
\hline Species & Percentage \\
\hline A. hydrophyla & $48.3 \%$ \\
A. allosacharophila & $17.2 \%$ \\
A. jandaei & $10.3 \%$ \\
HG2 & $3.0 \%$ \\
A. trota & $2.0 \%$ \\
A. sobria & $2.0 \%$ \\
Aeromonas sp. & $17.3 \%$ \\
\hline
\end{tabular}




\section{RESUMO}

\section{Aeromonas sp. e indicadores microbiológicos em fontes de água não tratada}

Bactérias do gênero Aeromonas são naturais no ambiente aquático e algumas espécies podem causar infecções em humanos como feridas, septicemia e diarréia. Este trabalho objetivou avaliar a ocorrência de Aeromonas sp. em 126 amostras de água de poços, nascentes, fontes e água mineral, e associar sua presença com indicadores microbianos de contaminação. Foi utilizada a técnica de membrana filtrante com o meio ADA e o teste P/A. Colônias típicas de Aeromonas sp. foram submetidas a testes bioquímicos para identificação da espécie. A produção de toxina foi avaliada utilizando-se células Y-1 de adrenal de camundongo. Coliformes e bactérias heterotróficas foram analisados através de filtração em membrana e pela técnica de inoculação em profundidade, respectivamente. P. aeruginosa, C. pefringens e os estreptococos fecais foram determinados pelo teste P/A. Aeromonas sp. foi isolada em 36,5\% das amostras, enquanto que os coliformes totais e termotolerantes estavam presentes em $51,2 \%$ e $23,8 \%$ das amostras, respectivamente. $C$. perfringens, estreptococos fecais e $P$. aeruginosa foram detectados em $16,5 \%, 20,4 \%$ e $3,8 \%$ das amostras respectivamente. Concentrações de bactérias heterotróficas superiores a 1,0x $10^{3} \mathrm{UFC} / \mathrm{mL}$ ocorreram em $52,5 \%$ das amostras. A. hydrophila foi a espécie mais isolada, seguida por A. allosaccharophila, A. jandaei, A. sobria e HG2. Uma toxina termolábil foi detectada em 13 dos 58 isolados analisados. Portanto, as fontes de água de consumo humano analisadas podem representar um risco para a saúde humana. É importante considerar que fontes, poços e nascentes são utilizadas como suprimento de água em áreas pobres e regiões rurais, onde predominam pessoas com problemas de desnutrição, mais suscetíveis a doenças infecciosas.

Palavras-chave: Aeromonas, água de consumo humano bruta, indicadores microbianos, toxina termolábil

\section{REFERENCES}

1. Alavandi, S.V.; Ananthan, S.; Pramod, N.P. (2001). Typing of Aeromonas isolates from children with diarrhoea and water samples by randomly amplified polyforphic DNA polymerase chain reaction and whole cell protein fingerprinting. Indian J. Med. Res., 113, 8597.

2. American Public Health Association. (1998). Standard Methods for the Examination of Water and Wastewater. $20^{\text {th }}$ edition, American Water Works Association, Water Environment Federation, Washington, DC.

3. Altewegg, M. (1999). Aeromonas and Plesiomonas. In: Murray et al. (eds). Man.Clin. Microbiol. ASM Press, Washington, DC, p.507-516.

4. Araujo, R.M.; Arribas, R.M.; Lucena, F.; Pares, R. (1989). Relation between Aeromonas and faecal coliforms in fresh waters. J. Appl. Bacteriol., 67, 213-217.
5. Araujo, R.M.; Arribas, R.M.; Pares, R. (1991) Distribution of Aeromonas species in waters with different levels of pollution. $J$. Appl. Bacteriol., 71, 182-186.

6. Ashbolt, N.J.; Ball, A.; Dorsch, M.; Turner, C.; Cox, P; Chapman, A.; Kirov, M. (1995). The identification and human health significance of environmental aeromonads. Water. Sci. Technol., 31(5-6), 263269.

7. Brandi, G.; Siste, M.; Giardini, F.; Schiavo, G.F.; Albano, A. (1999). Survival ability of cytotoxic strains of motile Aeromonas spp in different types of water. Lett. Appl. Microbiol., 29, 211-215.

8. Burke, V.; Robinson, J.; Gracey, M.; Peterson, D.; Partridge, K. (1984). Isolation of Aeromonas hydrophila from a metropolitan water supply: seasonal correlation with clinical isolates. Appl. Environ. Microbiol., 48(2), 361-366.

9. Clark J.A. (1968). Presence-absence test (P-A) test providing sensitive and inexpensive detection of coliforms, fecal coliforms, and fecal streptococci in municipal drinking water supplies. Can. J. Microbiol., 14, 13-18.

10. Clark J.A. (1969). The detection of various bacteria indicative of water pollution by a presence-absence procedure. Can. J. Microbiol., 15, 771-780.

11. Clark J.A. (1990). The presence-absence test for monitoring drinking water quality. In: Mc Feters G. A. (Ed.). Drinking Water Microbiology. Progress and recent developments. Springer-Verlag. New York, 1990.

12. Ghenghesh, K.S.; El-Ghodban, A.; Dkakni, R.; Abeid, S.; Altomi, A.; Tarhuni, A.; Marialigeti, K. (2001). Prevalence, species differentiation, haemolytic activity, and antibiotic susceptibility of Aeromonads in untreated well water. Mem. Inst. Oswaldo Cruz, 96(2), 169-173.

13. Hänninen, M.L.; Salmi, S.; Matilla, L.; Taipalinen, R.; Siitonen, A. (1995). Association of Aeromonas sp with travellers diarrhoea in Finland. J. Med. Microbiol., 42, 26-31.

15. Havelaar A.H.; During, M. Versteegh, J.F. (1987). Ampicilin-dextrin agar medium for the enumeration of Aeromonas species in water by membrane filtration. J. Appl. Bacteriol., 62, 279-87.

16. Havelaar, A.H.; Schets, F.M.; Van Silfhout, A.; Jansen, W.H.; Wieten, G.; Van Der Kooij, D. (1992). Typing of Aeromonas strains from patients with diarrhoea and from drinking water. J. Appl. Bacteriol., $72,435-444$.

17. Hirotani, H.; Sese, C.; Kagawa, H. (1999). Correlation of Aeromonas hydrophila with indicator bacteria of water quality and environmental factors in a mountain stream. Water Environ. Res., 71(12), 132-138.

18. Janda, J.M. (1991). Recent advances in the study of the taxonomy, pathogenicity and infectious syndromes associated with the genus Aeromonas. Clin. Microbiol. Rev., 4, 397-410.

19. Janda, J.M.; Abbot, S.L. (1998). Evolving concepts regarding the genus Aeromonas: an expanding panorama of species, disease presentations, and unanswered questions. Clin. Infect. Dis., 27, 33-344.

20. Joseph, S.W.; Carnahan, A.; Brayton, R.; Fanning, G.R.; Almazan, R.; Brabick, C.; Trudo Jr, E.W.; Colwell, R.R. (1991). Aeromonas jandaei and Aeromonas veronii dual infection of a human wound following aquatic exposure. J. Clin. Microbiol., 29(3), 565-569.

21. Joseph, S.W.; Carnahan, A. (2000). Update on the genus Aeromonas. ASM News, 66, 218-223.

22. Kühn, I.; Albert, M.J.; Ansaruzzaman, M.; Bhuiyan, N.A.; Alabi, S.A.; Islam, S.M.; Neogi, K.B.; Huys, G.; Janssen, K.K.; Möllby, R. (1997). Characterization of Aeromonas sp isolated from human with diarrhea, from healthy controls and from surface water in Bangladesh. J. Clin. Microbiol., 35(2), 369-373.

23. Lechevalier, M.W.; Evans, T.M.; Seidler, R.J.; Daily, O; Merrel, D.M.; Joseph, S.W. (1982). Aeromonas sobria in chlorinated drinking water suplies. Microbiol. Ecol., 8, 325-333.

24. Martin-Carnahan, A.; Joseph, S.W. (2005). Aeromonadaceae. In: Brenner, D.J.; Krieg, N.R.; Staley, J.T.; Garrity, G.M. (eds). Bergeys Manual of Systematic Bacteriology, The Proteobacteria, Part B. Vol.2, $2^{\text {nd }}$ ed., Springer-Verlag, New York, USA, p.556-578. 
25. Massa, S.; Altieri, C.; D'Angela, A.A.A. (2001). The occurrence of Aeromonas spp in natural mineral water and well water. Intern. J. Food Microbiol., 63, 169-173.

26. Merino, S.; Rubiers, X.; Knochel, S.; Tomás, J.M. (1995). Emerging pathogens: Aeromonas sp. Intern. J. Food Microbiol., 28, 157168.

27. Miñana-Galbis, D.; Farfán, M.; Lorén, J.G.; Fusté, M.C. (2002). Biochemical identification and numerical taxonomy of Aeromonas spp. isolated from environmental and clinical samples in Spain. $J$. Appl. Microbiol., 93(3), 420-430.

28. Pessoa, G.V.A.; Silva, E.A.M. (1974). Milieu pour l'indentification présomptive rapide des enterobactéries, des aeromonas et des vibrions. Ann. Microbiol. (Inst. Pateur), 125A, 341-347.

29. Pin, C.; Marin, M.L.; Selgas, D.; Tormo, M.L.G.J.; Casas, C. (1995). Differences in production of several extracellular virulence factors in clinical and food Aeromonas sp strains. J. Appl. Bacteriol., 78, 175-179.

30. Popoff, M. (1984). Aeromonas. In: Krieg, N.R., Holt, J.G. (Eds). Bergey's Manual of Systematic Bacteriology. Vol. 1. Williams and Wilkins. Baltimore, USA, 2005, p.545-548.
31. Razzolini M.T.P.; Bari, M.; Sanchez, P.S.; Sato, M.I.Z. (2001). Pesquisa de Aeromonas e suas toxinas em águas de consumo humano provenientes de caixas d'água e bebedouros. XXI Congresso Brasileiro de Microbiologia, Foz do Iguaçu, Resumos. Anais 2001.

32. Sack, D.A.; Sack R.B. (1975). Test for enterotoxigenic Escherichia coli using Y-1 adrenal cells in miniculture. Infect. Immun., 11, 224-336.

33. Sechi, L.A.; Deriu, A.; Falchi, M.P.; Fadda, G.; Zanetti, S. (2002). Distribution of virulence genes in Aeromonas spp isolated from Sardinian waters and from patients with diarrhoea. J. Appl. Microbiol., 92, 221-227.

34. Singh, D.V.; Sanyal, S.C. (1992). Haemolysin and enterotoxin production by Aeromonas caviae isolated from diarroeal patients, fish and environment. J. Diarrhoeal Dis. Res., 10(1), 16-20.

35. Warburton, D.W.; Dodds, K.L.; Burke, R.; Johnston, M.A.; Laffey, P.J. (1992). A review of the microbiological quality of bottled water sold in Canada between 1981 and 1989. Can. J. Microbiol., 38, 12-19.

36. USEPA. (2005). Drinking water contaminant candidate list. Federal Register, February 24, 2005. Volume 70, Number 36: 9071-9077. Available from [http: www.epa.gov./fedrgstr/epa-water/2005/ February/day 24/w3527.htm.] 